\title{
Manajemen Sumber Daya Manusia dan Pengaruhnya terhadap Kompetensi Guru Bidang Studi Kewarganegaraan pada Siswa Kelas VII SMP Negeri 1 Pajo Kabupaten Dompu Tahun Pelajaran 2018-2019
}

\author{
Fitriani $^{1}$ \\ email: yanifitriani1979@gmail.com
}

Astrak: Dalam proses belajar terdapat dua faktor utama, yakni guru dan siswa dengan latar belakang yang berbeda-beda. Perbedaan ini akan berpengaruh terhadap penerapan teori dan prinsip-prinsip belajar dalam pelaksanaan program belajar mengajar. Belajar mengajar merupakan suatu proses yang terpadu dalam suatu kegiatan manakala interaksi guru-siswa, siswa dengan siswa pada saat pengajaran itu berlangsung. Mengingat kedudukan siswa sebagai subyek yang menerima pelajaran (sasaran didik) dan sekaligus sebagai obyek dalam pengajaran, maka inti proses pengajaran tidak lain adalah kegiatan belajar siswa dalam suatu tujuan pengajaran. Proses belajar mengajar sebagai sistem instruksional mengandung berbagai unsur/ komponen yang satu sama lainnya saling terkait dan saling mendukung. Bertolak dari latarbelakang masalah di atas, maka ada beberapa rumusan masalah kemudian sebagai pangkal pembahasan ini adalah: 1). Apakah ada pengaruh manajemen sumber daya manusia dan pengaruhnya terhadap kompetensi guru bidang studi Kewarganegaraan pada siswa kelas VII SMP Negeri 1 Pajo Kabupaten DompuTahun Pelajaran 2018-2019?, 2). Bagaimanakah kompetensi guru bidang studi Kewarganegaraan pada siswa kelas VII SMP Negeri 1 Pajo Kabupaten Dompu terhadap manajemen sumber daya manusia. Adapun teknik pengumpulan data dalam penelitian ini Peneliti menggunakan beberapa metode sebagai berikut: (1) Tehnik Angket/ Kuesioner, (2) Tehnik Observasi atau Pengamatan, dan (3) Tehnik Dokumentasi. Satuan pelajaran atau persiapan mengajar mempunyai pengaruh yang positif yang terhadap hasil belajar yang dicapai siswa, hal ini sesuai dengan hasil perhitungan yang menunjukan nilai t hitung lebih besar dari nilai t tabel yakni sebesar $(4,038>2,04)$. Maka dengan demikian hipotesis alternatif yang diajukan diterima artinya Ada pengaruh positif yang signifikan antara penggunaan program satuan pelajaran terhadap hasil belajar siswa pada Mata Pelajaran Kewarganegaraan di SMP Negeri 1 Pajo Kabupaten Dompu Provinsi Nusa Tenggara Barat.

Kata Kunci: Manajemen Sumber Daya Manusia, Kompetensi Guru

${ }^{1}$ Dosen Tetap STAI Al-Amin Dompu 


\section{Pendahuluan}

Proses pembelajaran merupakan suatu proses yang mengandung serangkaian perbuatan guru dan siswa atas dasar hubungan timbal balik yang berlangsung dalam situasi edukatif untuk mencapai tujuan tertentu. Interaksi atau hubungan timbal balik antara guru dan siswa itu merupakan syarat utama bagi berlangsungnya proses pembelajaran. Interaksi dalam peristiwa belajar mengajar mempunyai arti yang lebih luas, tidak sekedar hubungan guru dan siswa, tetapi merupakan interaksi edukatif. Dalam hal ini bukan hanya penyampaian pesan berupa materi pelajaran, melainkan penanaman sikap dan nilai pada diri siswa yang sedang belajar.

Usman (1999:8) menjelaskan bahwa. Proses pembelajaran mempunyai makna dan pengertian yang lebih luas dari pada pengertian mengajar dalam proses pembelajaran tersirat adanya satu kesatuan kegiatan yang tidak dapat terpisahkan antara siswa yang belajar dengan guru yang mengajar. Antara kedua kegiatan ini terjalin interaksi yang saling menunjang yaitu antara guru dan siswa.

Guru merupakan faktor yang sangat dominan dan paling penting dalam pendidikan, karena bagi siswa guru sering dijadikan sebagai tokoh tauladan, bahkan menjadi tokoh identifikasi diri. Oleh sebab itu, guru seharusnya memiliki perilaku dan kemampuan yang memadai untuk mengembangkan diri siswa secara utuh. Untuk melaksanakan tugasnya dengan baik sesuai dengan prestasi yang dimilikinya, guru perlu menguasai berbagai hal sebagai kompetensi yang dimilikinya, (Wijaya, 1994:1).

Kedudukan guru dalam proses pembelajaran di kelas masih tetap memegang peranan penting. Peranan guru dalam proses pembelajaran di kelas belum dapat digantikan oleh mesin, radio, komputer atau internet yang modern sekalipun masih terlalu banyak unsur manusiawi, seperti sikap, sistem nilai, perasaan, motivasi, kebiasaan yang diharapkan merupakan dari proses belajar mengajar yang tidak dapat dicapai melalui alat-alat tersebut. Dari alat-alat tersebut atau teknologi yang diciptakan oleh manusia untuk membantu dan mempermudah kehidupannya, (Wijaya, 1994:13).

Hal ini menunjukkan bahwa mengajar merupakan suatu perbuatan yang memerlukan tanggung jawab moral yang cukup berat. Berhasilnya pendidikan pada siswa sangat bergantung pada pertanggungjawaban guru dalam melaksanakan tugasnya. Oleh sebab itu seorang guru harus peka dan tanggap terhadap perubahan-perubahan, pembaharuan serta ilmu pengetahuan dan tekhnologi yang terus berkembang sejalan dengan tuntutan kebutuhan masyarakat dan perkembangan zaman. Disinilah tugas guru untuk senantiasa meningkatkan wawasan ilmu pengetahuan, meningkatkan kualitas pendidikannya sehingga apa yang diberikan kepada siswanya tidak terlalu ketinggalan dengan perkembangan kemajuan zaman, (Usman, 2001:3).

Secara jujur harus diakui bahwa akhir-akhir ini masyarakat luas lebih banyak dipengaruhi oleh penggunaan istilah sehari-hari yang berasal dari budaya bangsa barat seperti Inggris dan yang lainnya. Ini merupakan salah satu hambatan dari beberapa hambatan untuk mempelajari mata pelajaran Kewarganegaraan. 
Tugas guru dalam kaitanya dengan motivasi belajar siswa pada mata pelajaran Kewarganegaraan di sekolah harus dapat menjadikan dirinya menjadi orang tua kedua. Ia harus mampu menarik simpati sehingga ia kemudian menjadi idola para siswa-siswanya. Pelajaran apapun yang diberikannya hendaknya dapat menjadi motivasi bagi siswanya dalam belajar. Bila seorang guru dalam penampilannya sudah tidak menarik maka kegagalan pertama adalah ia tidak akan menanamkan benih pengajaran itu kepada para siswanya, (Usman, 2001:7).

Berdasarkan hasil studi pendahuluan, proses pembelajaran mata pelajaran Kewarganegaraan di SMP Negeri 1 Pajo Kabupaten Dompu Provinsi Nusa Tenggara Barat siswa di samping harus menguasai materi baik kemudian mempraktikannya di depan kelas yang sesuai dengan yang ada dalam materi pelajaran juga langsung dipraktikkan pada saat proses pembelajaran berlangsung. Pelaksanaan pembelajaran mata pelajaran Kewarganegaraan tidak cukup dengan jumlah jam yang ditawarkan di Sekolah. Sehingga untuk menambah jam pembelajaran guru Kewarganegaraan melaksanakan proses pembelajaran di luar jam formal, sekalipun demikian para siswa kelihatannya tetap bersemangat untuk mengikuti proses pembelajaran mata pelajaran Kewarganegaraan. Kualitas Sumber Daya Manusia sampai saat ini masih tetap menjadi masalah yang utama dalam setiap usaha pambaharuan dalam sistem Pendidikan Nasional. Oleh karena itu, perlu dilakukan berbagai upaya pembaharuan melalui suatu sistem yang baku mencakup segala aspek/komponen pendidikan seperti pembaharuan kurikulum dan proses belajar mengajar, penyempurnaan sistem penilaian, pemakai metode yang bervariasi, penyempurnaan model satuan pelajaran dan usaha-usaha lain yang dapat mengarahkan aktivitas optimal belajar siswa.

Belajar merupakan proses yang dilakukan dengan sadar sebagai aktivitas mental/psikis yang berlangsung dalam interaksi aktif dengan lingkungan yang menghasilkan perubahan tingkah laku yang dalam pendidikan formal, perubahan tersebut meliputi tiga aspek yang tercermin yaitu aspek kognitif, aspek afektif, dan aspek psikomotorik, (Winkel, 1996:52).

Dengan demikian kegiatan belajar yang bermakna dalam proses belajar mengajar (pendidikan formal) adalah kegiatan yang mengakibatkan terjadinya peningkatan pengetahuan, sikap dan keterampilan pada diri individu yang sedang belajar. Perubahan-perubahan tersebut adalah dalam bentuk kemampuan-kemampuan baru yang dimiliki dalam waktu yang cukup lama dan berbekas. Perubahan-perubahan itu tidak terjadi seketika, akan tetapi karena adanya berbagai usaha yang telah dilakukan, baik oleh siswa itu sendiri, guru di sekolah serta lingkungan masyarakat.

Dalam proses belajar terdapat dua faktor utama, yakni guru dan siswa dengan latar belakang yang berbeda-beda. Perbedaan ini akan berpengaruh terhadap penerapan teori dan prinsip-prinsip belajar dalam pelaksanaan program belajar mengajar. Belajar mengajar merupakan suatu proses yang terpadu dalam suatu kegiatan manakala interaksi guru-siswa, siswa dengan siswa pada saat pengajaran itu berlangsung. Mengingat kedudukan siswa 
sebagai subyek yang menerima pelajaran (sasaran didik) dan sekaligus sebagai obyek dalam pengajaran, maka inti proses pengajaran tidak lain adalah kegiatan belajar siswa dalam suatu tujuan pengajaran. Proses belajar mengajar sebagai sistem instruksional mengandung berbagai unsur/komponen yang satu sama lainnya saling terkait dan saling mendukung.

Menurut (Nana Sudjana 1989) bahwa komponen-komponen dari suatu sistem pengajaran mencakup:

1) Tujuan pengajaran yaitu kemampuan dan tingkah laku yang diharapkan dikuasai siswa secara langsung setelah selesainya setiap interaksi belajar mengajar.

2) Materi atau bahan pelajaran yang perlu diberikan dan dikaji bersama untuk mencapai tujuan-tujuan yang diinginkan.

3) Metode atau alat yang digunakan dalam proses pengajaran.

4) Penilaian untuk mengetahui tingkat keberhasilan dari program bagi tercapainya tujuan-tujuan yang telah dirumuskan.

Hal di atas merupakan bagian-bagian integral yang tak terpisahkan satu sama lain dan harus dipenuhi dalam proses belajar mengajar. Komponen-komponen itu terintegrasi sebagai satu kesatuan di dalam sistem yang dirancang dan dituangkan dalam program satuan pelajaran.

Program satuan pelajaran harus disusun bertolak dari tujuan yang ingin dicapai. Oleh karena itu model satuan pelajaran yang digunakan harus berdasarkan GBPP agar proses belajar mencapai hasil belajar optimal yang diharapkan agar setiap mata pelajaran dapat terpenuhi khususnya pada mata pelajaran Kewarganegaraan. Seorang guru dituntut untuk menguasai dan memahami dengan tepat isi pesan pada GBPP untuk masing-masing mata pelajaran. Tidak terkecuali guru kewarganegraan, karena kewarganegaraan sebagai salah satu mata pelajaran yang diajarkan pada jenjang SMP dan SMA, sehingga guru harus mampu mempersiapkan proses belajar mengajar dan dapat menciptakan lingkungan belajar yang efektif dan lebih mampu dalam mengelola proses belajar mengajar sehingga hasil belajar siswa berada pada tingkat yang optimal. Penggunaan program satuan dalam kegaiatan proses belajar siswa agar proses belajar mengajar menjadi lebih terarah, yaitu dengan mencapai tujuan pembelajaran yang diharapkan, yakni meningkatkan hasil belajar atau prestasi belajar siswa.

Demikian juga halnya di SMP Negeri 1 Pajo Kabupaten Dompu, guru yang memegang mata pelajaran Kewarganegaraan juga menggunakan satuan pelajaran dalam melaksanakan kegiatan belajar mengajar. Namun yang menjadi permasalahan apakah dengan menggunakan satuan pengajaran akan mempengaruhi hasil belajar siswa atau sebaliknya tidak mempengaruhi hasil belajar siswa. Berdasarkan kenyataan inilah, maka penulis tertarik untuk mengkaji lebih jauh tentang manejemen sumber daya manusia dan kompetensi guru bidang studi Kewarganegaraan pada siswa kelas VII SMP Negeri 1 Pajo Kabupaten Dompu Tahun Pelajaran 2018-2019. 


\section{A. Rumusan Masalah}

Bertolak dari latar belakang masalah di atas, maka ada beberapa rumusan masalah kemudian sebagai pangkal pembahasan ini adalah:

1. Apakah ada pengaruh manajemen sumber daya manusia dan pengaruhnya terhadap kompetensi guru bidang studi Kewarganegaraan pada siswa kelas VII SMP Negeri 1 Pajo Kabupaten Dompu Tahun Pelajaran 2018-2019?

2. Bagaimanakah kompetensi guru bidang studi Kewarganegaraan pada siswa kelas VII SMP Negeri 1 Pajo Kabupaten Dompu terhadap manajemen sumber daya manusia?

\section{B. Tujuan Penelitian}

1. Ingin mengetahui apakah ada pengaruh manajemen sumber daya manusia dan pengaruhnya terhadap kompetensi guru bidang studi Kewarganegaraan pada siswa kelas VII SMP Negeri 1 Pajo Kabupaten Dompu Tahun Pelajaran 2018-2019.

2. Untuk mengetahui bagaimanakah kompetensi guru bidang studi Kewarganegaraan pada siswa kelas VII SMP Negeri 1 Pajo Kabupaten Dompu terhadap manajemen sumber daya manusia.

\section{Kegunaan Penelitian}

Kegunaan penelitian terdiri dari dua macam yaitu : kegunaan teoritis dan kegunaan praktis. Adapun hasil penelitian ini nantinya diharapkan mempunyai kegunaan sebagai berikut:

1. Kegunaan Teoritis

Dari hasil penelitian ini diharapkan dapat memberikan informasi yang bermanfaat bagi pengembangan ilmu pengetahuan khsususnya bagi para pengembang pengajaran mata pelajaran Kewarganegaraan. Sehingga mata pelajaran Kewarganegaraan dapat diajarkan oleh guruguru yang memiliki kompetensi dalam bidangnya, dengan demikian apa yang menjadi tujuan pengajaran mata pelajaran Kewarganegaraan dapat berhasil dengan baik.

2. Kegunaan Praktis

Dari hasil penelitian ini diharapkan dapat bermanfaat bagi para guru, khususnya guru bidang studi Kewarganegaraan untuk menjadikannya sebagai acuan dalam mengelola proses pembelajaran di kelas, sehingga ia sanggup menjadikan dirinya sebagai motivator bagi siswa dalam pembelajaran kewarganegaraan dengan lebih efektif dan efisien.

\section{Hipotesis}

Suryabrata (2000:69) mengatakan bahwa. Hipotesis adalah merupakan jawaban sementara terhadap masalah penelitian yang secara teoritis dianggap paling mungkin dan paling tinggi tingkat kebenarannya.

Berdasarkan dugaan sementara terhadap manejemen sumber daya manusia dan kompetensi guru bidang studi Kewarganegaraan pada siswa kelas VII SMP Negeri 1 Pajo Kabupaten Dompu, penulis mengajukan 
hipotesis alternatif terhadap masalah ini, yaitu ada pengaruh manejemen sumber daya manusia dan kompetensi guru bidang studi Kewarganegaraan pada siswa kelas VII SMP Negeri 1 Pajo Kabupaten Dompu.

\section{E. Manajemen sumber daya manusia}

\section{Pengertian manajemen sumber daya manusia}

Suatu perubahan struktural penyelenggaraan sekolah yang menekankan pada sekolah sebagai unit untuk peningkatan mutu pendidikan yang didukung oleh redistribusi kewenangan pembuatan keputusan. (Malen, Ogawa dan Karnz, 1990 dalam Duhou, 1999). Pendapat lain (Candoli, 1995 dalam Dohou, 1999) adalah suatu cara untuk memaksa sekolah itu sendiri mengambil tanggung jawab atas apa yang terjadi pada anak menurut jurisdiksinya dan mengikuti sekolah yang bertujuan untuk:

(a) Peningkatan efektivitas keputusan berkaitan dengan kebijakan pendidikan baik di tingkat sekolah maupun sistem

(b) Manajemen sekolah dan kepemimpinan yang meningkat

(c) Ketentuan penggunaan SDS lebih efesien

(d) Kualitas pengajaran yang meningkat

(e) Pengembangan kurikulum yang sesuai dengan kebutuhan sosial dan tenaga kerja di masa mendatang.

(f) Menghasilkan outcome siswa yang meningkat. (Towsand, 1997 dalam Duhou, 1999).

(g) Meningkatkan mutu pendidikan melalui peningkatan kemandirian, fleksibilitas, partisipasi, keterbukaan, kerjasama, akuntabilitas, sustainibilitas, dan inisiatif sekolah, dalam mengelola, memanfaatkan, dan memberdayan sumber daya yang tersedia.

(h) Meningkatkan keprdulian warga sekolah dan masyarakat dalam penyelenggaraan pendidikaan melalui pengembilan keputusan bersama.

(i) Meningkatkan tanggung jawab sekolah kepada orang tua, masyarakat, dan pemerintah untuk meningkatkan mutu sekolah.

(j) Meningkatkan kompetesi yang sehat antar sekolah dalam meningkatkan kualitas pendidikan.

\section{Pentingnya manajemen sumber daya manusia}

Pendidikan adalah usaha sadar dan bertujuan untuk mengembangkan kualitas manusia. Sebagai suatu kegiatan yang sadar akan tujuan, maka dalam pelaksanaannya berada dalam suatu proses yang berkesinambungan dalam setiap jenis dan Jenjang Pendidikan. Semuanya berkaitan dalam suatu Sistem Pendidikan yang Integral. (Djamarah, 2000:22).

Pendidikan juga dapat didefinisikan sebagai sistem yang utuh dengan bagian-bagian yang berinteraksi satu sama lain. Sistem secara sederhana dapat didifinisikan sebagai suatu kesatuan dari berbagai 
elemen atau bagian-bagiannya yang mempunyai hubungan fungsional dan berinteraksi secara dinamis untuk mencapai hasil yang diharapkan, (Mujiharjo,1993).

Berhasilnya suatu sistem sangat tergantung dari masukkan (input) yang digunakan dalam Proses Pendidikan tersebut, input dari Supra sistem diorganisasikan dan dikelola dengan pola menjadi subsistem yang saling mempunyai hubungan fungsional untuk mencapai tujuan. Input-input tersebut yaitu: (a) Tujuan, (b) Peserta didik, (c) Manajemen, (d) Struktur dan Waktu, (e) Materi, (f) Tenaga, (g) Alat Bantu belajar, (h) Fasilitas, (i) Teknologi, (j) Kendali Mutu, (k) Penelitian dan (l) Biaya Pendidikan

Dengan input yang baik, cenderung untuk menghasilkan pendidikan yang efektif dan efisien dalam proses pendidikan. Salah satu usaha untuk memperbaiki input di Pemerintahan Nusa Tenggara Barat adalah dengan melakukan peningkatan kualitas sumber daya manusia yang lebih baik. Peningkatan sumber daya manusia pada semua aspek Ilmu dengan mendorong setiap individu untuk selalu menyiapkan diri ke arah kemajuan merupakan cermin masyarakat maju, dan mau membuka diri terhadap perubahan yang selalu berjalan seiring dengan waktu, ke arah yang Positif dan Bermartabat. Peningkatan sumber daya manusia yang berkualitas dibidang Pendidikan dilakukan atas dasar bahwa:

a) Pesatnya Perkembangan Dunia Pendidikan

Dunia pendidikan adalah dunia dengan aktivitas keilmuan dan dunia perkembangan dalam arti yang positif, dimana ilmu berlomba untuk mendapatkan Ilmu Pengetahuan dengan prinsif Akademis, (Kebenaran, Kejujuran, dan Keadilan). Para pengelola pendidikan selalu berusaha untuk memberikan citra terbaik dari lembaganya dengan berbagai aktivitas serta dunia Kampus bukan hanya ajang Akademis tetapi bagian dari sistem industri secara keseluruhan dengan berpedoman pada prinsif masukan-proses dan manfaat (keuntungan) yang akan diperoleh bagi lembaga dan sekaligus bagi pemilik lembaga.

b) Tenaga Pengajar adalah Barometer Lembaga Pendidikan

Dengan penggunaan sistem yang ada diharapkan seluruh tenaga pengajar memiliki pemahaman yang mendalam tentang profesinya. Seorang tenaga pengajar adalah mereka yang selalu aktif dan selalu ingin tahu tentang dunia Pendidikan yang digeluti. Diantara penyiapan sumber daya manusia di Kabupaten Dompu, Provinsi Nusa Tenggara Barat, memang cukup memadai tetapi Komunitas Cendikia yang semakin banyak dari berbagai disiplin ilmu yang dapat memberikan kontribusi kepada pemerintah ke arah yang lebih baik, untuk masa depan anak bangsa yang lebih baik dari ini.

Di dalam Undang-Undang Dasar 1945 disebutkan adanya amanat untuk mencerdaskan kehidupan bangsa yaitu yang tercantum dalam Pembukaan Undang-Undang Dasar 1945 alenia ke empat yang 
menyebutkan sebagai berikut: Kemudian dari pada itu untuk membentuk suatu Pemerintahan Negara Indonesia yang melindung segenap Bangsa Indonesia dan seluruh tumpah darah Indonesia dan untuk memajukan kesejahteraan umum, mencerdaskan kehidupan Bangsa dan ikut melaksanakan ketertiban dunia ....."

Pembangunan Nasional di bidang Pendidikan adalah upaya mencerdaskan dan meningkatkan kualitas manusia Indonesia dalam mewujudkam masyarakat yang maju, adil dan makmur berdasarkan Pancasila dan Undang-Undang Dasar 1945 yang memungkinkan warganya untuk mengembangkan diri sebagai manusia Indonesia.

Pada tahun 2006 ini Negara kita telah memiliki UndangUndang Sistem Pendidikan Nasional yang baru, yaitu: Undang-Undang No. 20 tahun 2003 tentang Sistem Pendidikan Nasional. Tujuan Pendidikan Nasional yang baru, dirumuskan dalam Bab II Pasal 3 sebagai berikut: Pendidikan Nasional berfungsi mengembangkan kemampuan dan membentuk watak serta peradaban bangsa yang bermartabat dalam rangka mencerdaskan kehidupan bangsa, yang bertujuan untuk mengembangkan potensi peserta didik agar menjadi manusia yang beriman dan bertaqwa kepada Tuhan Yang Maha Esa, berakhlak Mulia, sehat, berilmu, Cakap, Kreatif, mandiri dan menjadi Warga Negara yang demokratis serta bertanggung jawab. Rumusan tentang tujuan Pendidikan Nasional di atas yang menjadi perhatian penulis yaitu mencerdaskan kehidupan bangsa, bertujuan mengembangkan potensi peserta didik. Proses Pendidikan terutama yang dilakukan di lembaga pendidikan formal. Sesuai dengan amanat pada Undang-Undang tersebut, harus mampu mencerdaskan dan mengembangkan potensi peserta didik. Hal ini tentu bukanlah sesuatu yang mudah karena masingmasing peserta didik memiliki pembawaan dan bakat yang berbedabeda. Tugas guru adalah mengoptimalkan proses Pendidikan dan pembelajaran serta proses peningkatan motivasi belajar pada peserta didiknya.

Dunia Pendidikan di Negara kita pada era sekarang ini sedang menghadapi berbagai tantangan yang amat kompetitif, sehingga membutuhkan kemampuan sumber daya manusia yang berkualitas tinggi. Dalam Undang-Undang No. 20 Tahun 2003 tentang sistem Pendidikan Nasional secara tersurat tentang fungsi Pendidikan Nasional sudah disebutkan di atas bahwa intinya mencetak sumber daya manusia yang berkualitas tinggi.

Persyaratan mutlak yang harus dimiliki manusia untuk bisa berkompetisi diera sekarang ini adalah penguasaan Imformasi dan Tekhnologi. Untuk bisa menguasai itu semua perlu adanya Proses Pendidikan dan Pembelajaran yang berkualitas. Oleh karena itu Pendidikan merupakan alternatif terbaik untuk menyiapkan sumber daya manusia yang berkualitas sehingga mampu menguasai imformasi dan Teknologi tersebut. Dalam menyiapkan sumber daya manusia yang berkualitas tinggi harus betul-betul terarah karena masyarakat di era sekarang ke depan merupakan masyarakat yang kompetitif. Ke depan 
kompetisi akan menjadi prinsif hidup. Anggota masyarakat yang tidak memiliki daya kompetisi tinggi akan tertinggal dan terpuruk.

Seiring dengan realitas di atas, Pendidikan dan Lembaga Pendidikan masa depan haruslah berkualitas, yang intinya mencakup Kualitas Input, Proses Output dan Outcome. Input mencakup Guru, Kepala Sekolah, Konselor, Karyawan dan Peserta Didik. Proses Pendidikan merupakan proses berlangsungnya sebuah aktivitas Pendidikan termasuk didalamnya proses pembelajaran. Output sekolah adalah Prestasi Sekolah yang dihasilkan. Sedangkan outcome adalah dampak yang ditunjukkan oleh keluaran yang berhasil dan dimanfaatkan masyarakat.

Kaitannya dengan masalah di atas, ada dua komponen pokok yang lebih dominan dalam mengambil peran dalam Proses Pendidikan yaitu Siswa dan Guru. Siswa sebagai pihak yang ingin mencapai tujuan, sedangkan guru sebagai pihak yang senantiasa berhubungan dengan siswa agar memotivasi dan membelajarkan siswa guna mencapai Tujuan Pendidikan.

Untuk mencapai tujuan pendidikan, antara siswa dan guru haruslah terjadi aktivitas yang timbal balik. Siswa harus mempuyai motivasi yang tinggi untuk berprestasi. Motivasi tinggi siswa untuk berprestasi haruslah didukung oleh aktivitas, peralatan pelajaran dan buku-buku pelajaran yang lengkap dan lain-lain. Guru haruslah senantiasa memotivasi siswanya untuk berprestasi dan senantiasa memberikan bimbingan belajar yang benar. Hal tersebut memang merupakan sesuatu yang ideal karena kenyataan di lapangan karakter setiap siswa berbeda-beda, kompetensi gurupun tidak sama.

Untuk mencapai prestasi belajar yang tinggi, selain guru yang memotivasi, orang tua juga berkewajiban mendorong anak-anaknya dalam berprestasi. Cara yang dilakukan orang tua antara lain perlu perhatian psikologis terhadap anak-anaknya. Anak perlu dicukupi semua kebutuhan belajarnya, misalnya buku-buku pelajaran, tempat belajar yang memadai dan sebagainya. Jadi cara-cara yang ditempuh orang tua terhadap prestasi belajar anaknya terkait erat dengan latar belakang pendidikan orang tua. Kecenderungan menunjukkan orang tua yang pendidikannya lebih tinggi relatif memperhatikan dan memotivasi anakanaknya untuk berprestasi. Begitu juga sebaliknya yakni orang tua yang berpendidikan rendah relatif kurang memperhatikan dan kurang mendorong terciptanya prestasi belajar siswa yang optimal. Kebutuhankebutuhan belajar siswa yang tak terpenuhi akan menghambat tercapainya prestasi belajar siswa yang optimal.

Dalam belajar, motivasi memegang peranan penting. Motivasi merupakan pendorong siswa dalam belajar. Intensitas belajar siswa sudah barang tentu dipengaruhi oleh motivasi. Pada umumnya semua siswa selama belajar sangat ingin mengetahui segala sesuatu dari apa yang dipelajarinya, sehingga dengan tujuan inilah akhirnya siswa terdorong untuk belajar dengan lebih giat dan lebih baik. Oleh karena itu, motivasi tidak bisa dipisahkan dari aktivitas belajar siswa. Siswa tidak 
akan mempelajari sesuatu bila hal itu tidak menyentuh kebutuhannya. Kebutuhan dan motivasi adalah dua hal yang saling berhungan sebab manusia hidup pada dasarnya tidak terlepas dari berbagai kebutuhan. Kebutuhan itulah yang nantinya mendorong manusia untuk senantiasa berbuat dan mencari sesuatu. Menurut Morgan dalam Djamarah (1994:27) mengemukakan: Manusia hidup memiliki kebutuhankebutuhan, yakni kebutuhan untuk berbuat suatu aktivitas, kebutuhan untuk menyenangkan orang lain, kebutuhan untuk mencapai hasil, dan kebutuhan untuk mengatasi kesulitan.

Semua kebutuhan sebagaimana dikemukakan di atas adalah kebutuhan-kebutuhan yang mendorong siswa untuk mempelajari sesuatu. Demi untuk menyenangkan kedua orang tuanya siswa giat belajar agar memperoleh nilai-nilai yang tinggi. Demi untuk memperoleh atau mencapai hasil belajar yang tinggi siswa giat belajar, baik siang maupun malam. Demi untuk mengatasi kesulitan agar mudah menjawab soal-soal ulangan, siswa giat belajar dan mempersiapkan bahan-bahan pelajaran yang belum rampung dan sebagainya. Dari aktivitas siswa yang demikian jelas, bahwa segala sesuatu yang akan dikerjakan siswa pasti bergayut dengan kebutuhannya. Kebutuhan itu sendiri adalah sebagai pendorong dari aktivitas belajar siswa. Kebutuhan dalam hal ini adalah prestasi belajar.

Seluruh aktivitas belajar siswa adalah untuk mendapatkan prestasi belajar yang baik. Setiap siswa pasti tidak ingin memperoleh prestasi belajar yang buruk. Oleh karena itu setiap siswa berlombalomba untuk mencapainya dengan melakukan suatu usaha yang seoptimal mungkin. Dalam hal yang demikian itu maka prestasi belajar bisa dikatakan sebagai kebutuhan yang memunculkan motivasi dari dalam diri siswa untuk selalu belajar.

\section{F. Kompetensi Guru}

\section{Pengertian Kompetensi Guru}

Kompetensi guru terdiri atas dua suku kata oleh karena itu untuk memperoleh kejelasan maknanya terlebih dahulu dijelaskan masing-masing suku katanya, yaitu kompetensi dan guru. Menurut W. Robert Houston kompetensi dapat diartikan sebagai suatu tugas yang memadai atau pemilikan pengetahuan, keterampilan yang dituntut oleh jabatan seseorang, (Djamarah, 1999:33).

Ahli lain mengatakan bahwa kompetensi adalah suatu hal yang menggambarkan kualifikasi atau kemampuan seseorang, baik yang kualitatif ataupun yang kuantitatif, (Usman, 2001:5).

Dari kedua pengertian di atas, maka dapat di simpulkan bahwa kompetensi adalah suatu tugas yang memadai atau pemilikan pengetahuan, keterampilan dan kemampuan yang dituntut dalam jabatan seseorang. Menurut N.A. Ametembun, guru adalah semua yang berwenang dan bertanggung jawab terhadap pendidikan muridmurid, baik secara individual ataupun klasikal, baik di sekolah maupun di luar sekolah, (Djamarah, 1994:33). Pendapat lain 
mengatakan bahwa guru merupakan jabatan atau profesi yang memerlukan keahlian khusus sebagai guru, (Usman, 1995:5).

Dari kedua pendapat di atas, maka dapat disimpulkan, bahwa guru adalah semua orang yang berwenang dan bertanggungjawab terhadap pendidikan murid-murid, baik secara individual maupun klasikal, baik di sekolah maupun di luar sekolah.

Dari uraian pengertian tentang kompetensi dan guru di atas maka yang dimaksud dengan kompetensi guru adalah pemilihan pengetahuan keguruan dan pemilikan keterampilan serta kemampuan sebagai guru dalam melaksanakan tugasnya.

\section{Pentingnya Kompetensi Guru}

Guru merupakan pendidik dan pengajar yang menyentuh kehidupan siswa yang oleh siswa sering dijadikan tokoh tauladan, bahkan menjadi tokoh identifikasi diri, oleh karena itu guru seharusnya memiliki prilaku yang memadai untuk dapat mengembangkan diri siswa secara utuh.

Wijaya (1994:34) mengatakan bahwa kehadiran guru dalam proses belajar mengajar atau pengajaran masih tetap memegang peran penting. Peranan guru dalam proses pengajaran belum dapat digantikan oleh mesin, radio, tape recorder ataupun komputer yang paling modern sekalipun. Masih terlalu banyak unsur manusiawi seperti sikap, sistem nilai, perasaan, motivasi, kebiasaan dan lain-lain yang merupakan hasil dari proses pengajaran yang tidak dapat dicapai melalui alat-alat tersebut. Karena itu, proses belajar mengajar sangat tergantung pada peranan guru dalam kegiatan pengajaran. Untuk itu, guru sebagai pengajar harus dapat menempatkan diri sebagai pemimpin belajar, fasilitator belajar, moderator belajar, motivator dan evaluator belajar yang obyektif dan komperhensif. Peranan tersebut menuntut adanya kualifikasi para guru, terutama kemampuan guru dalam mengorganisasikan kegiatan belajar mengajar, baik yang berkenaan dengan proses belajar siswa maupun dengan keterampilan mengajar, (Sudjana, 1996:48).

Dengan demikian, betapa pentingnya kompetensi guru dalam proses belajar mengajar. Karena itu dalam pengajaran kewarganegaraan sangat dibutuhkan guru yang memiliki kompetensi yang memadai sehingga kewarganegaraan sebagai bahan atau landasan untuk menguatkan hukum-hukum di dunia.

\section{Karakteristik Kompetensi Guru}

Karakteristik (ciri-ciri khusus) guru secara garis besar adalah sebagai berikut:

(a) Guru tersebut mengembangkan tanggungjawab dengan sebaikbaiknya.

(b) Guru tersebut mampu melaksanakan peranan-peranan secara berhasil.

(c) Guru tersebut mampu bekerja dalam usaha mencapai tujuan pendidikan di sekolah. 
(d) Guru tersebut mampu melaksanakan perannya dalam proses belajar mengajar di kelas,(Wijaya, 1994:9).

Dan untuk itu jelasnya karakteristik tersebut perlu ditinjau dari berbagai segi, yaitu:

1) Tanggung Jawab Guru

Wijaya (1994:9) mengatakan bahwa. Setiap guru harus memenuhi persyaratan sebagai manusia yang bertanggung jawab dalam bidang pendidikan. Guru sebagai pendidik bertanggung jawab untuk mewariskan nilai-nilai dan norma-norma kepada generasi berikutnya sehingga terjadi proses konservasi nilai-nilai baru.

Setiap tanggungjawab memerlukan sejumlah kemampuan dan setiap kemampuan dapat dijabarkan lagi dalam kemampuan yang lebih khusus, antara lain:

(a) Tanggung jawab moral, yaitu setiap guru harus memiliki kemampuan untuk menghayati prilaku dan etika yang sesuai dengan moral dan mengamalkannya dalam kehidupan seharihari. Karena itu, seorang harus menjadikan dirinya sebagai panutan atau sebagai teladan yang baik, terutama bagi para siswanya. Contoh ideal guru semacam ini adalah sang reformis baginda Nabi Muhammad SAW sebagaimana firman Allah:Artinya: Sesungguhnya pada diri Rasulullah itu terdapat suri tauladan yang baik bagimu, yaitu bagi siapa saja yang mengharapkan Allah dan hari akhirat. (Depag RI, 971:670).

(b) Tanggung jawab dalam pendidikan di sekolah yaitu sebagai guru harus menguasai cara belajar mengajar yang efektif, mampu membuat satuan pelajaran, mampu dan menguasai kurikulum dengan baik, mampu mengajar di kelas, menguasai teknis pemberian bimbingan dan layanan, mampu membuat dan melaksanakan evaluasi dan lain-lain.

(c) Tanggung jawab guru dalam bidang kemasyarakatan yaitu turut serta menyelesaikan pembangunan dalam masyarakat yakni untuk itu guru harus mampu membimbing, mengabdi dan melayani masyarakat sesuai dengan keilmuannya.

(d) Tanggung jawab guru dalam bidang keilmuan, yaitu guru selaku ilmuan yang bertanggung jawab dan turut serta memajukan ilmu terutama ilmu yang telah menjadi spesialisasinya, dengan melaksanakan penelitian dan pengembangan, (Wijaya, 1994:10).

2) Fungsi dan Peranan Guru

(a) Guru sebagai pendidik dan pengajar, yaitu harus memiliki kestabilan emosi, ingin memajukan siswa, bersifat teoritis, bersikap jujur dan terbuka, peka terhadap perkembangan terutama inovasi pendidikan. Untuk mencapai semua itu, guru harus memiliki dan menguasai berbagai jenis pembelajaran, manguasai teori dan praktik pendidikan, menguasai kurikulum dan metodologi pengajaran. 
(b) Guru sebagai anggota masyarakat, yaitu harus pandai bergaul dengan masyarakat. Untuk itu, guru harus menguasai psikologi sosial, memiliki pengetahuan tentang tentang hubungan antara manusia dan senagai anggota masyarakat, guru harus memiliki keterampilan membina kelompok, keterampilan bekerjasama dalam kelompok, keterampilan menyelesaikan tugas bersama dalam kelompok. Sebab sebagai manusia seorang guru tidak bisa memisahkan diri dengan kehidupan masyarakat. Oleh karena itu, seorang guru harus dekat dengan masyarakat di sekitar sekolahnya jauh atau dijauhkan dari masyarakat, karena hal tu akan menyebabkan hidupnya akan terhina sebagai mana firman Allah:ArtinyaMereka akan ditimpa kehinaan di manapun mereka berada kecuali dengan menjalin hubungan yang kuat dengan Allah dan hubungan yang kuat dengan sesama manusia. (Departemen Agama RI, 1971:94).

(c) Guru sebagai pemimpin, yakni harus mampu memimpin untuk itu guru perlu memiliki kepribadian, menguasai ilmu kepemimpinan, menguasai prinsip hubungan antara manusia, tehnik berkomunikasi, serta menguasai berbagai aspek kegiatan organisasi yang ada di sekolah.

(d) Guru sebagai pelaksana administrasi, yakni akan dihadapkan kepada administrasi-administrasi yang harus dikerjakan di sekolah. Untuk itu tenaga kependidikan harus memiliki kepribadian, jujur teliti, rajin, korespondensi, penyimpanan arsip dan ekspedisi serta administrasi pendidikan lainnya.

(e) Guru sebagai pengelola proses belajar mengajar, yakni harus menguasai situasi belajara mengajar, baik di dalam kelas maupun di luar kelas. (Wijaya, 1994:10-11).

3) Kriteria Menentukan Guru yang Kompetensi.

Setelah diuraikan pengertian, pentingnya karakteristik kompetensi guru, maka pada uraian berikut ini penulis akan membahas bagaimana kriteria untuk menentukan seorang guru itu kompeten atau tidak. Kriteria yang dimaksud disini adalah sebagai ukuran atau patokan dalam menentukan kompetennya guru. Dan guru yang dimaksud disini tentunya guru yang mengajarkan bidang studi Kewarganegaraan. Adapun kriteria yang dimaksud adalah sebagai berikut:

(a) Kriteria ditinjau dari sudut prosesnya (by process)

Untuk mengukur keberhasilan pengajaran dari sudut prosesnya dapat dikaji melalui beberapa persoalan di bawah ini:

(1) Apakah pengajaran direncanakan dan dipersiapkan terlebih dahulu oleh guru dengan melibatkan siswa secara sistematik ataukah suatu proses yang bersifat otomatis dari guru, disebabkan telah terjadi pekerjaan rutin? 
(2) Apakah kegiatan siswa belajar siswa dimotivasi guru sehingga ia melakukan kegiatan belajar dengan penuh kesadaran, kesungguhan dan tanpa paksaan untuk memperoleh tingkat penguasaan pengetahuan, kemampuan serta sikap yang dikehendaki dari pengajaran itu sendiri?

(3) Apakah siswa menempuh beberapa kegiatan belajar sebagai akibat penggunaan multi metode dan multi media yang dipakai guru, ataukah terbatas kepada satu kegiatan belajar saja?

(4) Apakah siswa mempunyai kesempatan untuk mengontrol dan menilai sendiri hasil belajar yang dicapainya ataukah ia tidak mengetahui apa yang ia lakukan itu benar atau salah?

(5) Apakah proses pengajaran dapat melibatkan semua siswa dalam kelas ataukah hanya siswa tertentu yang aktif belajar?

(6) Apakah suasana pengajaran atau proses belajar mengajar cukup menyenangkan dan merangsang siswa belajar ataukah suasana yang mencemaskan dan menakutkan?

(7) Apakah kelas memiliki sarana belajar yang cukup kaya, sehingga menjadi laboratorium belajar ataukah kelas yang hampa dan miskin dengan sarana belajar, sehingga tidak memungkinkan siswa melakukan kegiatan belajar yang optimal?

\section{Pengajaran ditinjau dari hasil yang dicapainya (by product)}

Adapun beberapa persoalan yang didapat dipertimbangkan dalam menentukan keberhasilan pengajaran ditinjau dari segi hasil atau produk yang dicapai siswa.

a) Apakah hasil yang dicapai siswa dari proses pengajaran nampak dalam bentuk perubahan tingkah laku secara menyeluruh (komprehensif) yang terdiri atas unsur kognitif, afektif, dan psikomotorik secara terpadu pada diri siswa ataukah hasil belajar yang bersifat tunggal atau terlepas satu sama lain sehingga tidak membentuk integritas pribadi?

b) Apakah hasil belajar yang dicapai siswa dari proses pengajaran mempunyai daya guna dan dapat diaplikasikan dalam kehidupan siswa, terutama dalam pemecahan masalah yang dihadapinya, ataukah suatu hasil yang sifatnya samar-samar sehingga tak banyak dan tak dapat diterapkan?

c) Apakah hasil belajar yang diperoleh/dicapai siswa tahan lama diingat dan mengendap dalam fikirannya serta cukup mempengaruhi prilaku dirinya, ataukah bersifat insidental masuk dari telinga kiri keluar lewat telinga kanan?

d) Apakah yakin bahwa perubahan yang ditunjukkan oleh siswa merupakan akibat dari proses pengajaran, ataukah perubahan itu 
sebagai akibat lain di luar proses pengajaran? (Sudjana, 2000:3539).

Ahli lain mengatakan, walaupun mengajar itu sangat kompleks, dapat kita tentukan beberapa kriteria untuk menilai guru itu.

a) Apakah guru itu hanya menggunakan satu metode, yakni metode kuliah, ataukah digunakannya berbagai metode mengajar sesuai dengan bahan yang diajarkannya?

b) Sanggupkah ia menimbulkan minat pada anak-anak?

c) Apakah ia mengajar dengan tujuan yang jelas hendak dicapainya dengan bahan pelajaran itu? Apakah tujuannya hanya menyampaikan ilmu atau juga membentuk pribadi anak?

d) Banyakkah digunakannya alat peraga untuk menjelaskan bahan yang diajarkannya?

e) Apakah ia memiliki kecakapan untuk menilai pekerjaan anak?

f) Apakah ia cukup mengajukakn pertanyaan?

g) Apakah ia menguasai bahan pelajaran sepenuhnya?

h) Apakah murid-murid diturut sertakannya dalam proses belajar itu?

i) Sanggupkah ia menguasai kelas?

j) Apakah guru itu hanya berpegang teguh pada buku pelajaran yang diajarkannya halaman demi halaman ataukah diusahakannya memberi anak-anak pengalaman yang luar dengan sumbersumber yang lain? (Nasution, 1986:21-22).

Dengan melihat uraian di atas maka ada beberapa prinsip yang berlaku umum untuk semua guru yang baik sebagai berikut:

a) Guru yang baik-baik memahami dan menghormati murid

b) Guru yang baik-baik harus menguasai bahan pelajaran yang diberikannya

c) Guru yang baik-baik menyesuaikan metode mengajar dengan bahan pelajaran

d) Guru yang baik-baik mengaktifkan murid dalam hal belajar

e) Guru yang baik-baik memberikan pengertian dan bukan hanya kata-kata belaka.

f) Guru yang baik menghubungkan pelajaran dengan kebutuhan murid.

g) Guru yang baik mempunyai tujuan tertentu dengan tiap pelajaran yang diberikan.

h) Guru yang baik yang terikat oleh satu textbook

i) Guru yang baik tidak hanya mengajar dalam arti menyampiakan pengetahuan saja kepada murid melainkan senantiasa mengembangkan pribadi anak.

\section{G. Desain Penelitian}

Sehubungan dengan pelaksanaan penelitian, maka peneliti telah mempunyai rencana kerja atau pedoman pelaksanaan penelitian dengan menggunakan pendekatan kuantitatif, karena data yang diperoleh nantinya tidak berupa pendapat-pendapat, konsep-konsep, keterangan, 
kesan-kesan, tanggapan, dan informasi yang berbentuk uraian dalam mengungkapkan masalah. Tetapi data tersebut menggambarkan jumlah atau bilangan yang memiliki perbandingan yang pasti, atau dengan tranfromasi lebih dahulu ke dalam simbol-simbol atau angka-angka dalam memberikan makna tentang sesuatu.

Desain penelitian merupakan strategi penelitian untuk memperoleh data yang valid sesuai dengan karakteristik variabel dan tujuan penelitian (Al-Hakim, dkk, 2002:8). Sedangkan pendapat lain mengatakan bahwa desain penelitian adalah rencana atau rancangan yang dibuat oleh peneliti, sebagai ancang-ancang kegiatan yang akan dilaksanakan, (Suharsimi Arikunto, 2002:45).

Sejalan dengan pendapat tersebut Margono, (1997:100) mengemukakan rancangan dalam penelitian merupakan keseluruhan proses pemikiran dan penentuan matang-matang yang akan dilakukan.

Berdasarkan pendapat di atas maka dapat dipahami bahwa yang dimaksud dengan desain penelitian adalah keseluruhan proses pemikiran dan penilaian tentang hal-hal yang akan diteliti. Corak penelitian ini sangat ditentukan oleh tujuan penelitian itu sendiri. Apabila suatu penelitian dapat diukur secara langsung dinilai dengan angka, maka penelitian ini dinamakan penelitian kuantitatif, sedangkan penelitian yang tidak dapat diukur atau dinilai dengan angka disebut dengan penelitian deskriptif kualitatif.

Dalam hal ini, peneliti menggunakan metode penelitian yang bercorak kuantitatif, karena peneliti bermaksud ingin meneliti tentang manajemen sumber daya manusia dan pengaruhnya terhadap kompetensi guru bidang studi Kewarganegaraan pada siswa kelas VII SMP Negeri 1 Pajo Kabupaten Dompu, dengan menggunakan desain berupa angka yang di analisis dengan statistik.

\section{H. Populasi dan Sampel \\ 1. Populasi}

Dalam suatu penelitian obyek penelitian merupakan suatu hal yang mutlak sebagai sumber data yang dalam penelitian kerap disebut dengan istilah populasi. Menurut Sugiyono, (2000:55) mengemukakan bahwa populasi adalah wilayah generalisasi yang obyek/ subyek yang mempunyai kualitas dan karakteristik tertentu yang ditetapkan oleh peneliti untuk dipelajari dan kemudian ditarik kesimpulannya.

Berdasarkan pendapat di atas pendapat dipahami bahwa populasi yang dimaksud adalah keseluruhan individu yang masingmasing memiliki sifat tertentu untuk diteliti. Sedangkan populasi yang dimaksud dalam penelitian ini adalah keseluruhan siswa kelas VII SMP Negeri 1 Pajo Kabupaten Dompu yang jumlahnya mencapai 391 orang siswa.

\section{Sampel}

Mengingat populasi tersebut yang cukup besar, maka Peneliti akan meneliti sebagian dari jumlah populasi yang ada, hal ini didasarkan atas pertimbangan dari segi waktu, tenaga dan dana yang 
tersedia. Menurut Margono (2004:121) mengemukakan bahwa "sampel adalah sebagai bagian dari populasi, sebagai contoh (monster) yang diambil dengan menggunakan cara tertentu.

Dari pendapat di atas dapat disimpulkan bahwa sampel adalah sebagian populasi yang akan menjadi obyek penelitian. Pengambilan sampel sebagai obyek penelitian dilakukan agar apa yang diteliti dapat mewakili dan menggambarkan secara maksimal keadaan populasi yang akan diteliti.

Adapun syarat utama dari sampel yang baik adalah bahwa sampel itu mencerminkan ciri-ciri atau sifat-sifat yang terdapat dalam populasi, dengan kata lain sampel yang baik adalah sampel yang refresentatif atau mencerminkan populasi dari pada sampel. Mengingat keterbatasan dana dan kekurangan waktu, sementara populasi yang akan diteliti terlalu besar, maka untuk mempermudah proses penelitian, akan digunakan teknik sampling. Apabila penelitian kurang dari 100 lebih baik diambil semuanya sehingga penelitiannya merupakan penelitian populasi, selanjutnya jika jumlah subyek besar dapat diambil antara $10 \%$ - 15\% atau antara $20 \%$ - 25\% atau lebih, (Suharsimi Arikunto, 1998:120).

Berdasarkan pendapat di atas, maka dalam penelitian ini sampelnya direncanakan sebesar $15 \%$ dari seluruh populasi. Penelitian dalam hal ini adalah sebagian siswa kelas VII SMP Negeri 1 Pajo Kabupaten Dompu yang berjumlah 391 siswa.

Cara yang digunakan oleh peneliti dalam pengambilan sampel penelitian dilakukan dengan menggunakan random sampling atau sampel acak. Random sampling ini diberi nama demikian karena di dalam pengambilan sampelnya peneliti mengambil sebagian dari jumlah siswa yang ada dalam kelas, dalam artian bahwa peneliti mengambil jumlah siswa dari masing-masing dengan menggunakan ukuran sampel 15\% sehingga perhitungannya menjadi $391: 100=58,65$ dan dibulatkan menjadi 59. Jadi karena jumlah kelas VII SMP Negeri 1 Pajo Kabupaten Dompu untuk kelas I berjumlah 3 kelas, maka 59 dibagi 8 sehingga hasilnya adalah 7,38 (Dibulatkan menjadi 7) sehingga sampelnya diambil masing-masing kelas adalah 7 orang siswa, dan dalam penelitian ini menggunakan random sampling yang semua obyek dianggap sama. Dengan demikian maka peneliti memberi hak yang sama pada setiap subyek untuk memperoleh kesempatan untuk dipilih menjadi sampel. Oleh karena itu, hak setiap subyek sama, maka peneliti terlepas dari perasaan ingin mengistimewakan satu atau beberapa subyek untuk dijadikan sampel. Setiap subyek terdaftar sebagai populasi, diberi nomor urut mulai dari satu sampai dengan 56 orang siswa. Di dalam pengambilan sampel peneliti terlebih dahulu menentukan besarnya jumlah sampel.

\section{Instrumen Penelitian}

Mengingat bahwa dengan diadakannya suatu penelitian di dalam mengumpulkan data-data, maka peneliti membutuhkan jenis-jenis 
instrumen penelitiannya supaya peneliti dalam mendapatkan data-data itu secara cepat, tepat dan baik yang diperlukan nanti.

Instrumen adalah alat pada waktu penelitian menggunakan suatu metode, (Arikunto Suharsimi, 2002:126). Ahli lain berpendapat bahwa Instrumen menekankan kepada alat atau cara untuk menjaring data yang diperlukan, (Sudjana, 2003:52). Jadi dapat disimpulkan bahwa Instrumen penelitian adalah alat atau fasilitas yang digunakan oleh peneliti dalam mengumpulkan data agar pekerjaannya lebih mudah dan hasilnya lebih baik, dalam arti lebih cermat, lengkap dan sistematis sehingga lebih mudah diolah. Untuk memudahkan dan memperlancar penelitian, peneliti menggunakan beberapa instrumen dalam mengumpulkan data yaitu:

\section{Angket/ Kuisioner}

Kuisioner adalah suatu alat pengumpul informasi dengan menyampaikan sejumlah pernyataan tertulis untuk dijawab secara tertulis juga oleh responden, (Margono, 2004:167). Sedangkan pendapat lain mengatakan bahwa angket atau Kuesioner adalah sejumlah pertanyaan yang tertulis yang digunakan untuk memproleh informasi dari responden dalam arti laporan tentang pribadinya, atau hal-hal yang diketahui, (Suharsimi Arikunto, 2002:128).

Dalam penelitian ini, peneliti menggunakan kuisioner tertutup atau terstruktur. Yang dimaksud dengan angket terstruktur adalah angket yang berisi pertanyaan-pertanyaan yang disertai sejumlah alternatif jawaban yang disediakan, responden dalam menjawab pertanyaannya terikat pada sejumlah kemungkinan jawaban yang sudah disediakan.

Data hasil angket tentang metode mengajar bervariasi berupa skor akhir yang diperoleh dari skor total dari 25 item pertanyaan dengan ketentuan sebagai berikut:

1) Jawaban selalu memperoleh skor 4

2) Jawaban sering memperoleh skor 3

3) Jawaban kadang-kadang memperoleh skor 2

4) Jawaban pernah memperoleh skor 1

5) Jawaban tidak pernah memperoleh skor 0

\section{Metode Observasi atau Pengamatan}

Observasi disebut juga pengamatan meliputi kegiatan pemusatan perhatian terhadap sesuatu objek dengan menggunakan seluruh alat indera. (Suharsimi Arikunto, 2002:133). Sedangkan Margono berpendapat bahwa observasi diartikan sebagai pengamatan dan pencatatan secara sistematik terhadap gejala yang tampak pada objek penelitian, (Margono, 2004:158).

Dari pendapat-pendapat di atas dapat dipahami bahwa observasi adalah pengamatan terhadap proses terjadinya suatu kegiatan dalam situasi tertentu.

\section{Metode Dokumentasi}

Metode Dokumentasi adalah salah satu metode pengumpulan data dengan jalan mempelajari dokumen-dokumen atau catatancatatan data tertulis yang bisa dipertanggungjawabkan kebenarannya. Sedangkan untuk meraih data tentang prestasi belajar metode yang 
diterapkan adalah metode dokumentasi, yakni suatu metode yang dapat diterapkan seperti yang dijelaskan dalam sebuah karya salah satu teknik pengumpulan data dengan cara meneliti dan mencatat benda-benda tertulis, gambar-gambar dan lain-lain yang berhubungan dengan objek penelitian, (Suharsimi Arikunto, 1998:116).

Penggunaan metode dokumentasi dalam pelaksanaan penelitian dimaksudkan untuk meraih data tentang prestasi belajar, dimana data telah tertuang di dalam dokumen sekolah. Metode Dokumentasi digunakan Peneliti, adalah untuk mendapatkan data tentang:

a. Manajemen sumber daya manusia dan (diambil dari data yang dimiliki oleh guru Bimbingan Penyuluhan/Bimbingan Konseling atau Tata Usaha).

b. Pengaruh Kompetensi Guru Bidang studi Kewarganegaraan. Data nilai yang dikumpulkan berupa nilai harian yang diperoleh dari rata-rata nilai ulangan harian dan rata-rata nilai tugas yang telah diolah. Nilai harian sebagai data nilai prestasi belajar siswa.

\section{J. Teknik Pengumpulan Data}

Pengumpulan data merupakan bagian yang sangat penting dalam penelitian. Kegiatan ini membutuhkan keseriusan dan penuh hati-hati guna mandapatkan data yang valid. Oleh Karena itu dalam melaksanakan kegiatan ini diperlukan teknik yang tepat. Adapun teknik pengumpulan data dalam penelitian ini Peneliti menggunakan beberapa metode sebagai berikut:

\section{Tehnik Angket/ Kuesioner}

Kuesioner adalah sejumlah pertanyaan tertulis yang digunakan untuk memperoleh informasi dari responden dalam arti laporan tentang pribadinya atau hal-hal yang ia ketahui, (Suharsimi Arikunto, 2002:128).

Dalam penelitian ini peneliti menggunakan kuesioner tertutup yang maksudnya jawabannya sudah disediakan oleh peneliti sehinngga responden tinggal memilih jawaban yang sesuai dengan keadaan yang sebenarnya. Sehubungan dengan hal tersebut peneliti ingin mendapatkan data tentang metode yang diterapkan oleh guru khususnya guru mata pelajaran Kewarganegaraan

\section{Tehnik Observasi atau Pengamatan}

Observasi diartikan sebagai pengamatan dan pencatatan secara sistematik terhadap gejala yang tampak pada objek penelitian, (Margono, 2004:158). Dari pendapat tersebut dapat dipahami bahwa observasi adalah pengamatan terhadap proses terjadinya suatu kegiatan dalam situasi tertentu. Observasi yang peneliti gunakan dalam penelitian ini adalah observasi non sistematis. Peneliti menggunakan metode ini untuk memperoleh data tentang gambaran umum lokasi penelitian. 


\section{Tehnik Dokumentasi}

Yang dimaksud dengan metode dokumentasi adalah mencari data mengenai hal-hal atau variabel yang berupa catatan, transkrip, buku-buku, majalah, prasasti, notulen rapat, agenda dan sebagainya.

Menurut Margono (2004:181) menyatakan metode dokumentasi adalah cara mengumpulkan data melalui pengamatan tertulis seperti arsip-arsip dan termasuk juga buku tentang pendapat, teori, dalil atau hukum-hukum dan lain-lain yang berhubungan dengan masalah penelitian.

Berdasarkan pendapat di atas bahwa metode dokumentasi adalah cara mengumpulkan data mengenai hal-hal tertentu melalui pencatatan yang tertulis. Penelitian menggunakan metode ini untuk memperoleh data tentang Kompetensi guru khsususnya pada mata pelajaran Kewarganegaraan yang diambil melalui raport.

\section{K. Teknik Analisis Data}

Analisa data merupakan cara yang dipergunakan dalam pengolahan data yang diperoleh dari penelitian yang menggunakan berbagai macam metode-metode sehingga dapat memperoleh informasiinformasi yang berdayaguna dan berhasil tepat guna sebagaimana yang diharapkan. Data yang telah diperoleh tersebut dianalisis dengan teliti sehingga dapat disimpulkan sebagai bahan dalam penelitian.

Menurut Suharsimi Arikunto, (1997:203) mengemukakan bahwa secara garis besar pekerjaan menganalisis data meliputi tiga langkah yaitu: (1) Persiapan, (2) Tabulasi, dan (3) Penerapan data sesuai dengan pendekatan penelitian.Berikut ini Peneliti uraikan satu demi satu:

\section{1) Persiapan}

Kegiatan peneliti dalam langkah persiapan antara lain:

a) Mengecek nama dan kelengkapan identitas pengisi dalam hal ini peneliti akan mengecek kembali identitas, observasi, hasil pengukuran kemampuan siswa melalui pengisian angket dengan jawabannya sampai kepada skorsing atau penghitungan hasil jawaban yang diberikan oleh responden.

b) Mengecek kelengkapan data artinya peneliti memeriksa kembali instrumen pengumuman data termasuk kelengkapan lembaran instrumen

c) Mengecek macam isian data. Maksudnya apabila dalam instrumen terdapat satu atau beberapa item yang diisi tidak tahu padahal isi yang tersebut merupakan variabel pokok dalam item, maka item tersebut harus hilangkan.

2) Tabulasi

Tabulasi dapat dilakukkan jika semua masalah yang berhubungan persiapan sudah terselesaikan.

3) Penerapan data sesuai dengan pendekatan penelitian

Penerapan data yaitu mengolah data yang diperolah dengan menggunakan rumus-rumus statistik sesuai dengan pendekatan penelitian. Pendekatan penelitian yang peneliti gunakan adalah 
pendekatan kuantitatif. Dalam penerapan atau menganalisis data yang terkumpul, peneliti menggunakan analisis statistik. Adapun rumus yang digunakan dalam penelitian ini.

\section{Sarana Prasarana SMP Negeri 1 Pajo Kabupaten Dompu}

Sarana dan prasarana pendidikan yang dimiliki oleh SMP Negeri 1 Pajo Kabupaten Dompu dapat dilihat pada tabel di bawah ini:

Tabel 2: Keadaan Inventaris SMP Negeri 1 Pajo Kabupaten Dompu

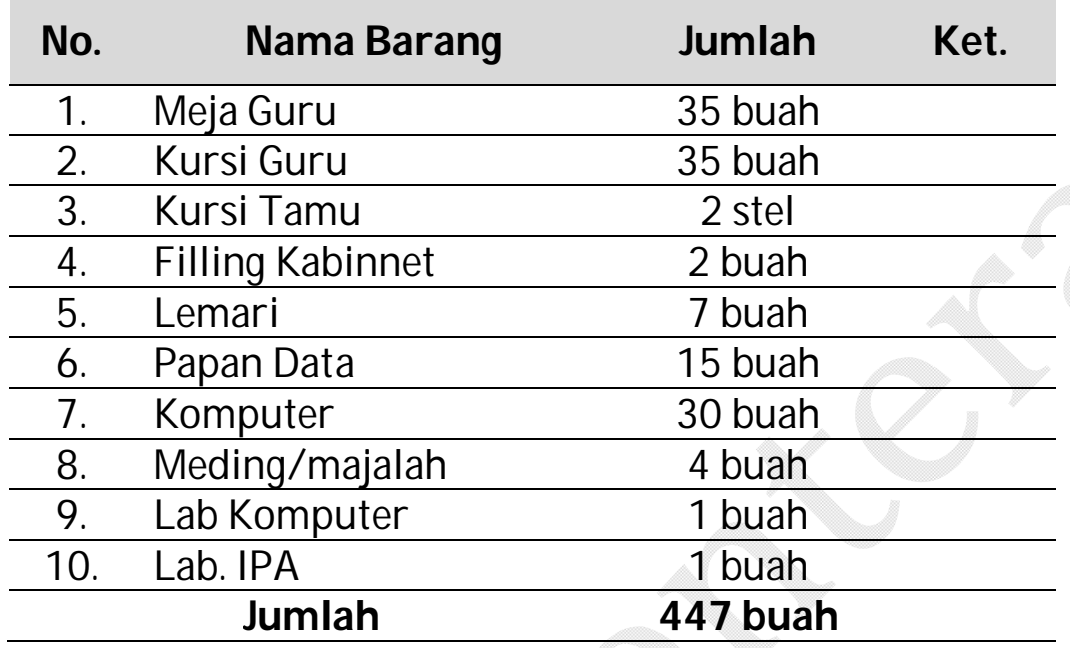

Sumber Data: Papan data di ruangan TU bagian Pengarsipan

Dari tabel di atas, maka fasilitas yang dimiliki oleh di SMP Negeri 1 Pajo Kabupaten Dompu masih kurang sehingga sekolah tersebut membutuhkan fasilitas yang lebih banyak untuk melangsungkan kegiatan belajar mengajar yang efektif.

\section{Keadaan Guru/ Pegawai SMP Negeri 1 Pajo Kabupaten Dompu}

Guru sebagai tenaga edukatif merupakan salah satu yang menentukan dalam pencapaian suatu tujuan pendidikan. Dengan demikian halnya dengan tenaga tata usaha yang tidak kalah pentingnya sebagai tenaga administratif dalam mengelola proses belajar mengajar. Tenaga pendidikan maupun tenaga administratif di SMP Negeri 1 Pajo Kabupaten Dompu tidak jauh beda dengan madrasah negeri lainya, yakni kebanyakan tenaga honorer yang digaji menurut jamnya ditambah dengan uang transportasi dan tunjangan lainya.

\section{Keadaan Siswa SMP Negeri 1 Pajo Kabupaten Dompu}

Pada suatu lembaga pendidikan siswa atau anak didik merupakan salah satu faktor utama dalam proses belajar mengajar, karena tanpa adanya siswa dalam suatu lembaga pendidikan tersebut tidak akan terlaksana.Pada Tahun Pelajaran 2018-2019 siswa SMP Negeri 1 Pajo Kabupaten Dompu 559 orang. Untuk lebih jelasnya jumlah siswa SMP Negeri 1 Pajo Kabupaten Dompu dapat dilihat pada tabel berikut: 
Tabel 4: Data Keadaan Siswa/ siswi SMP Negeri 1 Pajo

Kabupaten Dompu

\begin{tabular}{|c|c|c|c|c|c|}
\hline \multirow[b]{2}{*}{ No } & \multirow{2}{*}{ Kelas } & \multicolumn{2}{|c|}{ Jumlah Siswa } & \multirow{2}{*}{ Jumlah } & \multirow{2}{*}{ Ket } \\
\hline & & Laki-laki & Perempuan & & \\
\hline \multirow[t]{6}{*}{1.} & VII A & 13 & 17 & 30 & \\
\hline & VII B & 21 & 17 & 39 & \\
\hline & VII C & 17 & 21 & 38 & \\
\hline & VII D & 18 & 19 & 37 & \\
\hline & VII E & 19 & 19 & 38 & \\
\hline & Jumlah & 88 & 93 & 182 & 182 \\
\hline \multirow[t]{7}{*}{2 . } & VIII A & 16 & 17 & 33 & \\
\hline & VIII B & 15 & 19 & 34 & \\
\hline & VIII C & 14 & 19 & 33 & \\
\hline & VIII D & 17 & 15 & 32 & \\
\hline & VIII E & 16 & 17 & 33 & \\
\hline & Jumlah & 78 & 87 & 165 & 165 \\
\hline & & & \multicolumn{2}{|c|}{$x^{2}+2$} & \\
\hline \multirow[t]{7}{*}{3.} & IXA & 20 & 15 & 35 & \\
\hline & IX B & 19 & 16 & 35 & \\
\hline & IXC & 19 & 16 & 35 & \\
\hline & IX D & 18 & 15 & 33 & \\
\hline & IXE & 19 & 15 & 34 & \\
\hline & IXF & 20 & 14 & 34 & \\
\hline & lah & 115 & 91 & 206 & 206 \\
\hline \multirow{2}{*}{\multicolumn{2}{|c|}{$\begin{array}{l}\text { Jumlah siswa } \\
\text { Keseluruhan }\end{array}$}} & & & & \\
\hline & & 281 & 271 & 553 & 553 \\
\hline
\end{tabular}

Dari tabel di atas, menunjukan bahwa siswa/ siswi SMP Negeri 1 Pajo Kabupaten Dompu dapat bertambah siswa pada tiap tahun pelajaran sehingga kelas satu dan kelas dua dibagi menjadi dua kelas yakni kelas VII, kelas VIII, dan kelas IX.

\section{Penyajian Data}

Dalam penelitian ini yang menjadi subyek penelitiannya adalah siswa kelas VII yang terdiri dari 3 kelas. Adapun kelas yang diambil menjadi kajian dalam penelitian adalah kelas VII SMP Negeri 1 Pajo Kabupaten Dompu di mana kegiatan dalam proses belajar mengajar guru menggunakan satuan pelajaran. Dalam penelitian ini, pada saat proses belajar mengajar dilakukan dengan tiga kali pertemuan oleh guru dalam penggunaan progran satuan pelajaran yang sudah terlampir, guru akan menggunakan metode ceramah dan tanya jawab dalam menyampaikan pelajaran kepada siswa agar siswa menerima pelajaran yang baik.

Adapun dalam penelitian ini adalah peneliti menggunakan teknik tes dan dokumentasi. Dengan tehnik tersebut kegiatan belajar mengajar yang dilakukan pada masing-masing kelas baik kelas VIII sebagai kelas 
kontrol maupun kelas VIII sebagai kelas eksperimen. Dengan tes yang digunakan adalah jenis test multiple choise atau pilihan ganda dengan menggunakan lima option yaitu a, b, c, d, dan e dengan 20 butir test yang sudah terlampir. Jadi data yang dapat diperoleh melalui tes adalah data tentang hasil belajar siswa tanpa program satuan pelajaran sebagai kelas VIII dan data tentang hasil belajar siswa menggunkan program satuan pelajaran sebagai kelas eksperimen kelas VIII pada mata pelajaran Kewarganegaraan kelas VII semester I di SMP Negeri 1 Pajo Kabupaten Dompu Tahun Pelajaran 2018-2019.

\section{N. Pembahasan}

Berdasarkan hasil analisa data yang diperoleh, ternyata persiapan mengajar mempunyai kontribusi terhadap hasil belajar siswa pada mata pelajaran Kewarganegaraan kelas VII semester VIII di SMP Negeri 1 Pajo Kabupaten DompuTahun Pelajaran 2018-2019. Hasil belajar siswa dipengaruhi oleh berbagai faktor, seperti persiapan mengajar guru. Karena persiapan mengajar selalu berkenaan dengan proyeksi atau perkiraan mengenai apa yang akan dilakukan dalam kegiatan belajar mangajar. Dengan demikian persiapan mengajar dalam kegiatan belajar memang sangat penting untuk mencapai tujuan yang telah direncanakan.

Hal ini sesuai dengan pendapat David Johnson dalam (Suryosubroto, 2000) bahwa seorang guru sebelum mengajar hendaknya merencanakan program, membuat persaiapan mengajar yang hendak diberikan, merencanakan dalam menyampaikan materi pelajaran, karena semua itu akan dapat memudahkan siswa dalan belajar (yang terdiri ruang kelas, siswa, materi, dan kurikulum) agar belajar menjadi lebih mudah.

Dengan demikan dapat dikatakan bahwa persiapan mengajar yang baik akan dapat meningkatkan hasil belajar siswa atau sebaliknya dengan tidak baiknya persiapan mengajar maka hasil siswa cendrung menurun. Ini sejalan dengan pendapat Usman dalam bukunya yang berjudul Menjadi Guru Profesional yang mengatakan bahwa dalam proses belajar mengajar sebagian besar hasil belajar peserta didik ditentukan oleh peranan guru. Guru yang kompoten akan lebih mampu dalam mempersiapkan pengajaran dan dapat menciptakan lingkungan belajar yang efektif dan akan lebih mampu dalam mengelola proses belajar mengajar, sehingga hasil belajar siswa berada pada tingkat yang optimal, (Usman, 2002:7).

Jadi, keberhasilan proses belajar mengajar sangat ditentukan oleh kemampuan guru dalam mempersiapakan pengajaran dan mengelola proses belajar mengajar. Dengan demikian persiapan mengajar yang dibuat oleh guru merupakan salah satu faktor pendukung dari pada hasil belajar siswa, sehingga masalah persiapan mengajar ini tidak kalah pentingnya, bahkan bisa dijadikan sebagai barometer untuk mengukur keberhasilan siswa untuk mencapai hasil belajar yang lebih baik. 


\section{Kesimpulan}

Satuan pelajaran atau persiapan mengajar mempunyai pengaruh yang positif yang terhadap hasil belajar yang dicapai siswa, hal ini sesuai dengan hasil pehitungan yang menunjukan nilai t hitung lebih besar dari nilai $t$ tabel yakni sebesar $(4,038>2,04)$. Maka dengan demikian hipotesis alternatif yang diajukan diterima artinya Ada pengaruh positif yang signifikan antara penggunaan program satuan pelajaran terhadap hasil belajar siswa pada Mata pelajaran Kewarganegaraan di SMP Negeri 1 Pajo Kabupaten Dompu Provinsi Nusa Tenggara Barat.

\section{P. Saran-saran}

Bertolak dari hasil penelitian dan kesimpulan dalam penelitian ini, maka di sarankan kepada:

a. Kepala Sekolah

Di sarankan agar kebijakan, dukungan dan partisipasi yang sudah terlaksana kiranya dapat ditingkatkan. Disamping itu juga disarankan bagi Kepala Sekolah hendaknya dapat melakukan monitoring dan supervisi kepada guru untuk dapat melakukan kegiatan belajar mengajar yang efektif.

b. Saran Guru

Disarankan bagi guru-guru untuk menyusun dan mengggunakan satuan pelajaran, dan selalu meningkatkan diri dalam memotivasi dan memacu hasil belajar siswa di sekolah dimana berada, sehingga tujuan pendidikan dapat tercapai secara optimal

c. Siswa

Siswa sebagai sasaran pendidikan, disarankan agar memiliki motivasi dalam memanfaatkan waktu belajarnya baik pada mata pelajaran Kewarganegaraan maupun mata pelajaran lain yang dipelajari. Hal ini penting artinya, karena keberhasilan dari proses pembelajaran tergantung sungguh pada siswa itu sendiri (internal), disamping faktor luar (ekstern).

d. Peneliti Selanjutnya

Meskipun penelitian ini telah nampak hasilnya, maka disarankan kepada peneliti selanjutnya agar dapat mengembangkan sesuai dengan disiplin ilmu yang dimiliki oleh calon peneliti.

\section{Daftar Rujukan}

Aqib, Zainal. 2003. Profesionalisme Guru Dalam Pembelajaran, Insan Cendikiawan: Surabaya

Arikunto, Suharsimi. 1997. Prosedur Penelitian Suatu Pendekatan Praktek. PT.Rineka Cipta: Jakarta

Balen, S. 2005. Apa, Mengapa dan Bagaimana Kurikulum Berbasis Kompetensi (KTSP).Departemen Pendidikan Nasional, Jakarta

Barlow, 1985 Educational PsycologyThe Teaching and Learning Process. Jakarata. 
Dakir, H. 2004. Perencanaan dan Pengembangan Kurikulum. PT. Rineka Cipta, Jakarta.

Departemen Pendidikan dan Kebudayaan. Inovasi Pendidikan Dalam Upaya Peningkatan Profesionalisme Tenaga Kerja Pendidikan. Balai Pustaka, Bandung:

Depdiknas. 2004. Kurikulum SMA, Pedoman Khusus Pengembangan Silabus dan Penilaian.Balai Pustaka, Jakarta

Djamarah, Bahri Syaiful. 1994. Prestasi Belajar dan Kompetensi Guru.Usaha Nasional, Surabaya

Djiwandono, E.W.1989 Psikologi Pendidikan. P2LPTK. Jakarta

Echols, John, M dan Shadily Hasan. 2003. Kamus Inggris Indonesia, and English Indonesian Dectionary, Gramedia Pustaka Utama: Jakarta Hari Sudrajat, 2004 Implementasi KTSP H. CV. Cipta Cekas grafika. Bandung

Manan. 1989. Dasar-Dasar Sosial Budaya Pendidikan. PPLPTK: Jakarta

Mariot, 2002 Manajemen SDM. PT. Grasindo, Jakarata.

Muchlish, Masnur. 2007. Seri Standar Nasional Pendidikan KTSP (Kurikulum Tingkat Satuan Pendidikan) Dasar Pemahaman dan Pengembangan Pedoman Bagi Pengelola Lembaga Pendidikan, Pengawas Sekolah, Komite Sekolah, Dewan Sekolah, dan Guru, Bumi Aksara: Jakarta

Mulyasa 2004. Kurikulum Tingkat Satuan Pendidikan Sebuah Panduan Praktis, PT. Remaja Rosda Karya: Bandung.

Nur Hidayat, 1989. Persepsi siswa-mahasiswa Non PBB Tentang Pengajaran Dengan Prestasi Belajar Psikologi. Pusat Penelitian IKIP Malang, Malang.

Nur Kencana, W. dan Sumarta 1992. Evaluasi Ilmu Pendidikan. Usaha Nasional, Surabaya

Nurhadi. 2003. Pembelajaran Kontekstual dan Penerapannya Dalam Kurikulum Berbasis Kompetensi. Universitas Negeri Malang,. Malang

Porwodarminto, W.J.S. Kamus bahasa Indonesia. Balai Pustaka, Jakarta

Prayitno, E. 1989. Motivasi Dalam Belajar. P2LPTK, Jakarta

Roestiyah, N.K. 1992. Masalah-masalah Ilmu Keguruan. Bia Aksara, Jakarta

Sardiman, A.M.1990. Interaksi dan Motivasi Belajar Mengajar, Pedoman Bagi Guru dan Calon Guru. Rajawali Pers, Jakarta

Saripuddin, U.1989. Konsep dan Strategi Pendidikan Moral Pancasila di Sekolah menengah (Suatu Penelitian Kepustakaan). P2LPTK, Jakarta

Sastrawijaya, T. 1988. Proses belajar Mengajar di Perguruan Tinggi. P2LPTK, Jakarta.

Sitorus, J.1990. Metodologi Penelitian Pendidikan. Tarsito, Bandung.

Slameto 2003 Belajar \& Faktor-faktor yang mempengaruhinya, Remika Cipta, Jakarata.

Sudjana, Nana.1989. Dasar-Dasar Proses Belajar Mengajar. Sinar Baru Algasindo: Bandung.

Sumadi Suryabrata, 2000. Metodelogi Penelitian. Penerbit CV. Rajawali. Jakarta.

Suparmin, 2003.Motvasi dan Etos Kerja Guru, Depag, Jakarta.

Suprihatini, Amin. Panduan Praktis Mengajar IPS Terpadu Kelas X. Cempaka Putih, Klaten. 
Suyudi, A. 1989. Motivasi belajar Mahasiswa.Tidak di Publikasikan. Pusat Penelitian IKIP Malang, Malang

Tu'u Tulus, 2004 Peran Disiplin pada prilaku \& Prestasi siswa, Grasindo, Jakarta.

Usman, dkk. 2001. Upaya Optimalisasi Belajar Mengajar, Bandung: PT. Remaja Rosdakrya.

Weda, IGL Ngurah,2007. Pengaruh Penerapan KBK terhadap Motivasi dan Prstasi Belajar KWn,?:Mataram.

Winkel, W.S. 1987. Psikologi Pendidikan dan Evaluasi Belajar. Jakarta : Gramedia.

Yamin, Martinis, 2006 Profesionalisensi Guru \& Implementasi KBK, Gaung Persada Press: Ciputat. 